\title{
Investigation of the Hydrologic Monitoring Network of the Willcox and Douglas Basins of Southeastern Arizona: A Project of the Rural Watershed Initiative
}

The Willcox and Douglas Basins, about $1,910 \mathrm{mi}^{2}$ and $750 \mathrm{mi}^{2}$, respectively, are in Cochise and Graham Counties in southeastern Arizona (fig. 1). The majority of the population in the two basins resides in the cities of Willcox and Douglas where the population in 2000 was 3,733 and 14,312, respectively (U.S. Census Bureau, 2005). The projected population in 2025 for the city of Willcox is 3,981 and for Douglas is 16,642 (Arizona Department of Economic Security, 2005).

Ground water is the main source of water in this area owing to the sparse surface-water resources. The Willcox and Douglas Basins are the primary areas of agriculture in Cochise County, and 90 percent of the ground-water pumpage is for agriculture. According to the National Agricultural Statistics Service, irrigated land increased 25 percent from 52,000 acres in 1992 to 65,000 acres in 2002 (U.S. Department of Agriculture, 1999, 2004).

There is concern in the Willcox and Douglas Basins about the future availability of water for all uses, including agriculture, municipal and domestic, and thermoelectric power. Comprehensive monitoring of the ground-water system and identification of the areas of change will help managers with future resource decisions. Ground-water pumping commonly causes declines in ground-water levels. When declines become widespread and persistent, further negative consequences such as increased pumping lift, land subsidence, and deterioration in water quality can occur. The combined estimated ground-water pumpage in both

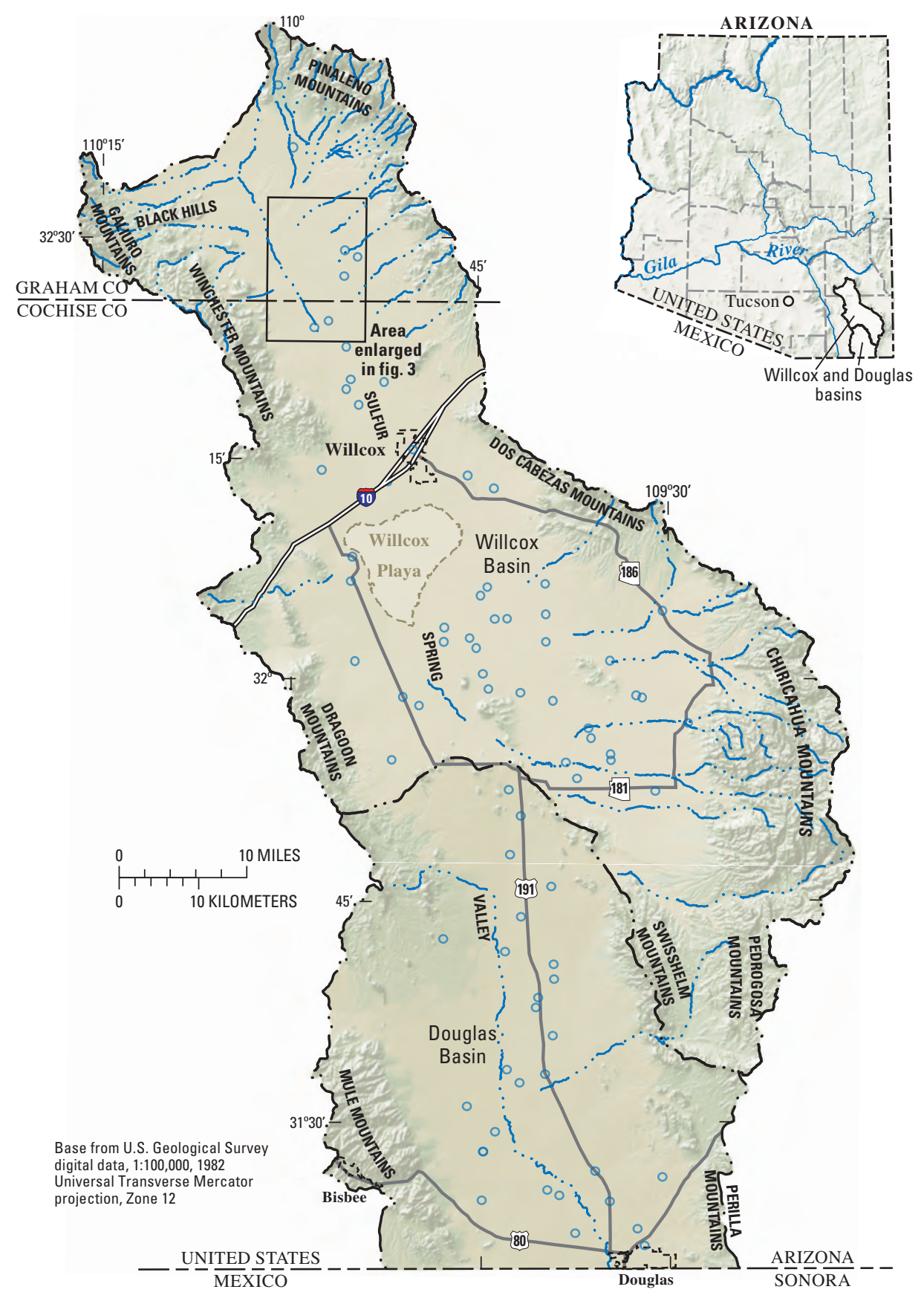

Figure 1. Physiography and location of water-level monitoring sites in Willcox and Douglas Basins. 


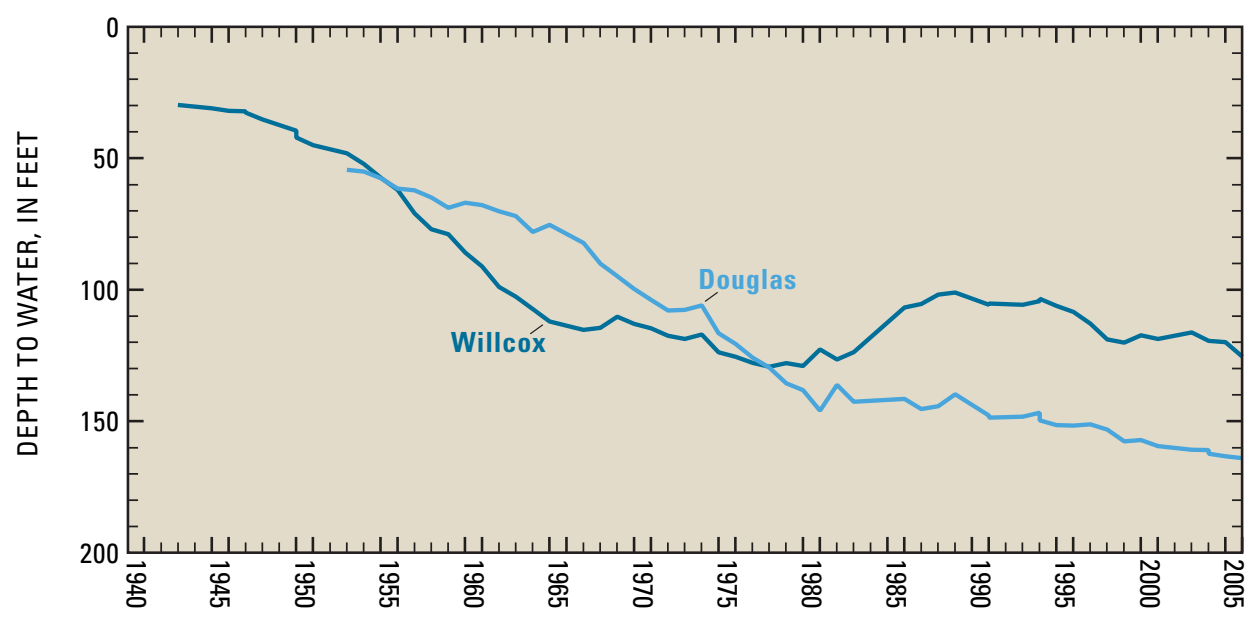

Figure 2. Hydrographs of depth to water for wells in the Willcox and Douglas Basins.

basins from 1915 to 2000 was more than 12 million acre-feet. These withdrawals have resulted in large declines in groundwater levels in both basins (fig. 2).

In 1965, the State Land Commission declared much of the Douglas Basin a Critical Groundwater area because the large withdrawals for irrigation resulted in large water-level declines. The commission prohibited drilling new irrigation wells except to replace existing wells. The Critical Groundwater area became the Douglas Irrigated NonExpansion Area (INA) with the passage of the 1980 Groundwater Management Act. The INA designation means that only land irrigated any time between 1975 and 1980 can be irrigated with ground water (Rascona, 1993). There is no such limitation on irrigation in the Willcox Basin.

In 2005, the U.S. Geological Survey (USGS), in cooperation with the Arizona Department of Water Resources (ADWR), began an investigation of the geology and hydrology of the Willcox and Douglas Basins (primarily focusing on the hydrologic monitoring network) as part of the Rural Watershed Initiative (RWI). The RWI is a program established by the State of Arizona in 1999 and managed by the ADWR. Other RWI investigations that started in 2005 are the middle San Pedro Basin in southeastern Arizona, and the Detrital, Hualapai, and Sacramento Valleys in northwestern Arizona. RWI studies in the Coconino Plateau, the Mogollon Highlands, and the upper and middle Verde River watersheds (http:// az.water.usgs.gov/rwi-ii/) began in 1999 .

The purpose of this study is to evaluate the data-collection network that is used to monitor hydrologic conditions and ground-water storage changes in the Willcox and Douglas Basins. The study will be conducted in two phases. The Willcox Basin will be studied in the first phase, and the Douglas Basin will be studied in the second phase. The primary objectives are to:

1. Assess (a) the current state of knowledge of the ground-water flow systems, and (b) the existing water-level data collection networks and needs for improvement.

2. Improve the understanding of the hydrogeologic framework of the Willcox Basin.

3. Establish a hydrologic monitoring network for ongoing assessments and changes in aquifer conditions.

4. Inform the hydrologic community and residents of the Willcox and Douglas areas about hydrologic conditions in the basins.

5. Evaluate historical and current estimates of ground-water withdrawal for agricultural use.

\section{Physical Setting}

The Willcox and Douglas Basins form the Sulfur Springs Valley, a structural northwest-trending valley in southeastern Arizona. The Willcox Basin is surrounded by the Dragoon and Winchester Mountains on the west, the Galiuro Mountains and Black Hills on the north, and the Pinaleno, Dos Cabezas, and Chiricahua Mountains on the east. The southern boundary of the Willcox Basin is the Swisshelm Mountains and a series of small hills at the northern end of the Douglas Basin. The Douglas Basin is surrounded by the Swisshelm, Pedrogosa, and Perilla Mountains on the east, and the Mule and Dragoon Mountains on the west. The Douglas Basin extends into northern Mexico, but the southern boundary of the study area is the United States-Mexican border. The elevation in the study area ranges from $10,700 \mathrm{ft}$ in the Pinaleno Mountains on the northern boundary to $3,900 \mathrm{ft}$ at the international boundary.

The Willcox Basin has internal drainage where all surface water drains to the Willcox Playa, a prominent feature of about $50 \mathrm{mi}^{2}$ in the center of the basin. A few streams in the Pinaleno and Chiricahua Mountains are perennial. All other streams in the basin are ephemeral. The Douglas Basin is drained by Whitewater Draw, which heads in the Chiricahua Mountains in the southern part of the Willcox Basin and flows westward around the north end of the Swisshelm Mountains southward through the basin and into Mexico. Most streams in the basin, including Whitewater Draw, are ephemeral. Leslie Creek, which originates in the Pedrogosa Mountains and the southern end of the Chiricahua Mountains, has a perennial reach.

\section{Climate}

The climate in both basins is semiarid and characterized by cool winters and hot summers. The average annual daily minimum and maximum temperatures in the city of Willcox are $41^{\circ} \mathrm{F}$ and $77^{\circ} \mathrm{F}$, respectively (Western Regional Climate Center, 2005). The minimum temperature recorded in Willcox was $-7^{\circ} \mathrm{F}$ and the maximum temperature was $110^{\circ} \mathrm{F}$. In the city of Douglas, the average annual daily minimum and maximum temperatures are $45^{\circ} \mathrm{F}$ and $79^{\circ} \mathrm{F}$, respectively (Western Regional Climate Center, 2005). The minimum temperature recorded in Douglas was $2^{\circ} \mathrm{F}$ and the maximum temperature was $109^{\circ} \mathrm{F}$.

Average annual precipitation in the two basins ranges from $12 \mathrm{in.} \mathrm{on}$ the basin floor to more than 35 in. in the surrounding mountains (Spatial Climate Analysis Service, Oregon State University, 2004). Precipitation occurs during two seasons. During the winter months frontal storms bring widespread rainfall, and during summer months thunderstorms may produce localized, heavy rainfall of short duration. Average annual snowfall ranges from about 1 to 4 in. on the basin floor to 13 in. in the higher elevations. Native vegetation in 
the noncultivated areas on the basin floor and foothills in the two basins is mainly mesquite and sagebrush with some cactus. Vegetation in the higher elevations is primarily pine. The Willcox Playa, an alkali flat, is devoid of vegetation.

\section{Hydrology and Water Use}

Ground water from the basin-fill aquifer is the primary source of water for the Willcox and Douglas Basins. In the Willcox Basin, the basin fill or alluvial deposits consist of stream deposits and lake-bed deposits (Brown and Schumann, 1969). The stream deposits are the most productive water-bearing units and are composed of gravel, sand, silt, and clay. The lake-bed deposits, composed mostly of clay, can function as a confining layer to the water in the underlying stream deposits, creating artesian conditions, or can cause ground water to be perched above them where they underlie the stream deposits (Mann and others, 1978). In the Douglas Basin the basin fill is composed of sand and gravel lenses interbedded with silt and clay lenses. The sand and gravel lenses are the main source of water. There are no large scale confining layers in the Douglas Basin; however, there are localized areas with confined or perched water conditions (Arizona Department of Water Resources, 1994). The surrounding mountains are composed of igneous, metamorphic and sedimentary rocks.

There was a large range in the depth to ground water in the monitoring wells measured by the ADWR in 2003. Depth to ground water in the Willcox Basin ranged from $30 \mathrm{ft}$ to more than 400 ft below land surface. In the Douglas Basin, depth to ground water ranged from $60 \mathrm{ft}$ to more than $300 \mathrm{ft}$ below land surface. Prior to development, the ground-water flow was similar to the surface drainage, but large scale groundwater pumping has created cones of depression that have changed groundwater flow in parts of the two basins. Several large cones of depression have developed in the Willcox Basin. One is southeast of the Willcox Playa, and the other is about 6 mi northwest of the city of Willcox (Mann and others, 1978; Oram, 1993). In the Douglas Basin, a large cone of depression has formed in the northern part of the basin (Mann and English, 1980; Rascona, 1993).

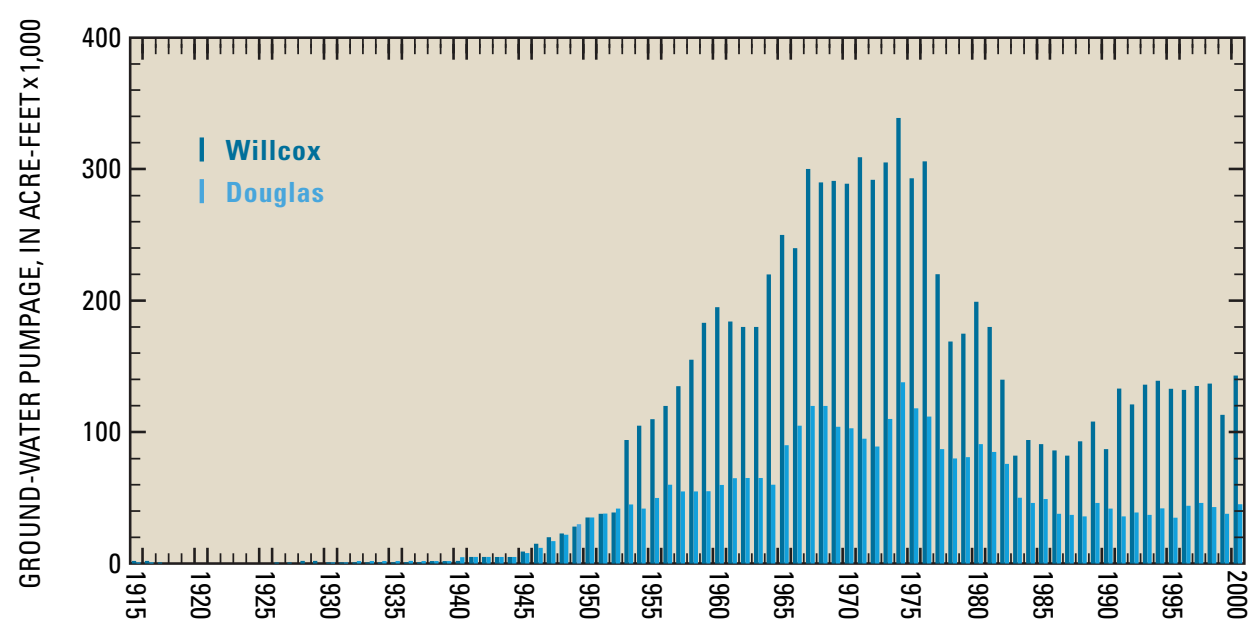

Figure 3. Annual ground-water pumpage in the Willcox and Douglas Basins, 1915-2000.
Ground-water storage in the upper $1,200 \mathrm{ft}$ of the basin fill in the Willcox Basin in 1989 was estimated to be 45.3 million acre-ft (Arizona Department of Water Resources, 1994). Freethey and Anderson (1986) estimated that the amount of recoverable water to a depth of 1,200 ft in the Douglas Basin is 32 million acre-ft. Recharge in both basins is primarily along the mountain front. There is additional recharge from irrigation water and from runoff in stream channels. Estimated recharge in the Douglas Basin is 22,000 acre-ft per year (Coates and Cushman, 1955; Freethey and Anderson, 1986). Estimated recharge in the Willcox Basin is 47,000 acre-ft per year on the basis of a numerical ground-water model (Anderson and Freethey, 1995).

Prior to 1945 , the estimated annual ground-water pumpage in both basins was less than 5,000 acre-ft. After 1945, ground-water pumpage increased and the maximum annual pumpage in both basins was reached in 1974 at 339,000 acre-ft in the Willcox Basin and 138,000 acre-ft in the Douglas Basin (Anning and Duet, 1994). Reduction of irrigated acreage resulted in a decline in annual pumpage in both basins between 1974 and the early 1980s. Pumpage stabilized between 1991 and 2000 and averaged 41,000 acre-ft per year in the Douglas Basin and 132,000 acre-ft per year in the Willcox Basin (fig. 3).

Ground-water withdrawals have resulted in large declines in ground-water levels in both basins and may be the cause of land subsidence in the Willcox Basin. Water levels declined more than $200 \mathrm{ft}$ in nine wells in the Willcox Basin between 1954 and 1975 (Mann and others, 1978). Subsidence occurs when there is significant ground-water withdrawal and resulting compaction of the unconsolidated aquifer. Holzer (1980)

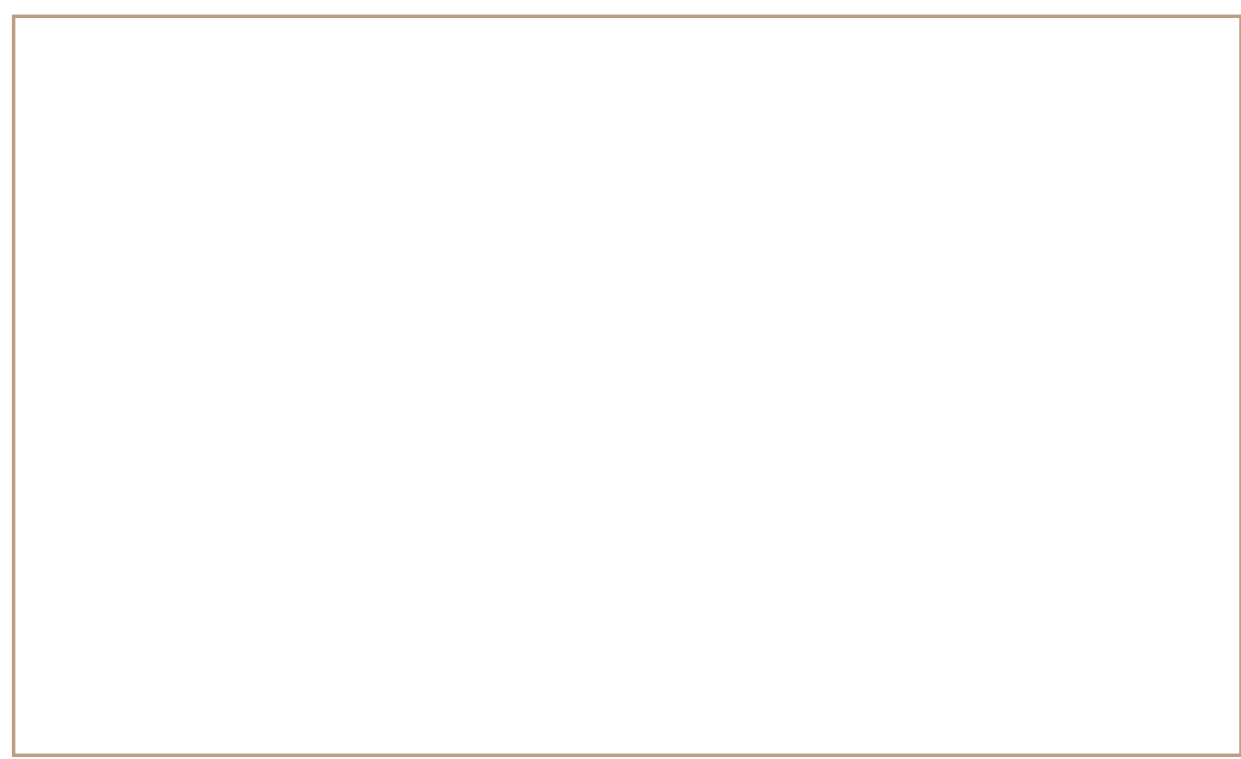

Figure 4. Earth crack south of Willcox, August 2005. 
reported that about $5 \mathrm{ft}$ of subsidence had been measured between 1937 and 1974 northwest of Willcox. Some of the earth cracks and fissures found in the Willcox Basin could be related to the subsidence and to the declines in water levels (Holzer, 1980; fig. 4).

\section{Planned Approach of Investigation}

The initial task of the investigation will be to compile hydrologic data and information. Data and information will be compiled first for the Willcox Basin and then for the Douglas Basin.

Ground-water level monitoring networks in the two basins will be evaluated to determine if sufficient data are being collected to document ground-water conditions and changes in the ground-water system. The areal distribution of the sites in the networks will be evaluated on the basis of land use and ground-water withdrawals. Time series water-level data will be plotted to determine if data from the network are representing changes in the hydrologic conditions as noted in published literature. In 2004, there were 46 wells in the ADWR groundwater level monitoring network in the Willcox Basin and 27 in the Douglas Basin (fig. 1). If it is determined that additional sites are needed to augment the current network, the new sites will be selected on the basis of well-construction information documented in various databases, lithology from well logs, field inventories, and statistical techniques.

A ground-water storage-change monitoring network using gravity methods will be established to complement the ground-water level monitoring network. Gravity monitoring locations will be selected throughout the basins, with special emphasis on areas where groundwater levels can not be obtained.

A preliminary assessment of subsidence in the Willcox Basin will be done by using remote sensing techniques. A spatial database of the surface cracks and earth fissures will be created. Some will be mapped in the field by using the Global Positioning System (GPS).

A major portion of the water budget in the Willcox and Douglas Basins is ground-water pumpage for irrigation of crops. The pumpage for irrigation of crops in 2006 will be estimated by mapping irrigated acreage, crop type, and irrigation method (fig. 5). Estimates of pumpage for previous years also will be evaluated. This information will be used to develop a spatial database.

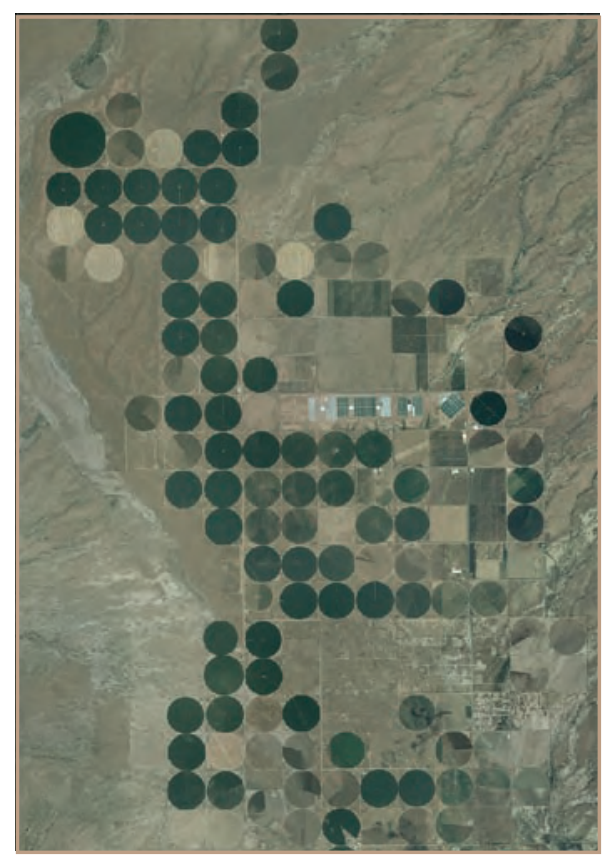

Photograph courtesy of United States Department of Agriculture-National Agriculture Imagery Program

Figure 5. Aerial photograph of irrigated area in the northern part of the Willcox Basin, July 2005 (see fig. 1).

Reconnaissance geophysical surveys will be done in the Willcox Basin. These surveys will provide some information on the distribution and properties of basinfill sediments.

\section{-A.D. Konieczki}

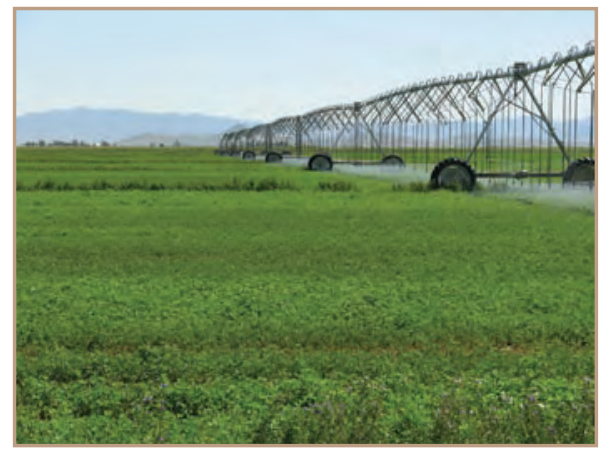

\section{References Cited}

Anderson, T.W., and Freethey, G.W., 1995, Simulations of ground-water flow in alluvial basins in south-central Arizona and parts of adjacent States: U.S. Geological Survey Professional Paper 1406-D, 78 p.

Anning, D.W., and Duet, N.R., 1994, Summary of ground-water conditions in Arizona 1987-90: U.S. Geological Survey Open-File Report 94-476, 1 sheet.
Arizona Department of Economic Security, 2005, 2004 Estimates - Population growth, accessed November 11, 2005, at http://www.workforce. az.gov.us

Arizona Department of Water Resources, 1994, Arizona Water Resources Assessment, Volume I, Inventory and Analysis, and Volume II, Hydrologic Summary: Arizona Department of Water Resources, 236 p.

Brown, S.G., and Schumann, H.H., 1969, Geohydrology and water utilization in the Willcox Basin, Graham and Cochise Counties, Arizona: U.S. Geological Survey Water-Supply Paper 1859-F, 32 p.

Coates, F.T., and Cushman, R.L., 1955, Geology and ground-water resources of the Douglas basin, Arizona: U.S. Geological Survey WaterSupply Paper 1354, 56 p.

Freethey, G.W., and Anderson, T.W., 1986, Predevelopment hydrologic conditions in the alluvial basins of Arizona and adjacent parts of California and New Mexico: U.S. Geological Survey Hydrologic Investigations Atlas HA-664, 3 sheets.

Holzer, Thomas L., 1980, Reconnaissance maps of earth fissures and land subsidence, Bowie and Willcox areas, Arizona: U.S. Geological Survey Map MF-1156, 2 sheets, scale 1:24,000.

Mann, Larry J., and English, C.S., 1980, Maps showing ground-water conditions in the Douglas basin area, Cochise County, Arizona-1978: U.S. Geological Survey Water-Resources Investigations Open-File Report 80-700, 3 sheets.

Mann, L.J., White, N.D., and Wilson, R.P., 1978, Maps showing ground-water conditions in the Willcox area, Cochise and Graham Counties, Arizona-1975: U.S. Geological Survey WaterResources Investigations Open-File Report 78-60, 3 sheets.

Oram, Paul III, 1993, Maps showing groundwater conditions in the Willcox Basin Graham and Cochise Counties, Arizona-1990: Arizona Department of Water Resources Hydrologic Map Series Report Number 25, 2 sheets.

Rascona, S.J., 1993, Maps showing groundwater conditions in the Douglas Basin, Cochise County, Arizona-1990: Arizona Department of Water Resources Hydrologic Map Series Report Number 26, 2 sheets.

Spatial Climate Analysis Service, Oregon State University, 2004, Analysis of annual precipitation: Spatial Climate Analysis Service, Oregon State University, accessed January 10, 2006, at http://www.ocs.orst.edu/prism/products/ matrix.phtml?vartype $=\mathrm{ppt}$

U.S. Census Bureau, 2005, City \& Town Population Estimates, accessed February 10, 2006, at http:// www.census.gov/popest/cities/.

U.S. Department of Agriculture, 1999, 1997 Census of Agriculture-Volume 1: National, state, and county tables, accesses January 12 , 2006, at http://www.nass.usda.gov/Census_of Agriculture/index.asp

U.S. Department of Agriculture, 2004, 2002 Census of Agriculture-Volume 1: National, state, and county tables, accesses January 12, 2006, at http://www.nass.usda.gov/Census of Agriculture/index.asp

Western Regional Climate Center, 2005, Arizona Climate Summaries, 2005, accessed November 21, 2005, at http://www.wrcc.dri.edu/summary/ climsmaz.html

For further information, contact: A. D. Konieczki

U.S. Geological Survey Arizona Water Science Center 520 North Park Avenue, Suite 221 Tucson, Arizona, 85719-5035

Email: alicek@usgs.gov or visit home page at http://az.water.usgs.gov 